\title{
Arrested development of abomasal trichostrongylid nematodes in lambs in a steppe environment (North-Eastern Algeria)
}

\author{
Salah Meradi ${ }^{1}$, Jacques Cabaret ${ }^{2, *}$, and Bourhane Bentounsi ${ }^{3}$ \\ 1 Institute of Veterinary and Agronomic Sciences, Batna University 1, 05000 Batna, Algeria \\ 2 ISP, INRA and University F. Rabelais, 37380 Nouzilly, France \\ 3 Institute of Veterinary Sciences, Constantine University 1, 25000 Constantine, Algeria
}

Received 25 April 2016, Accepted 28 August 2016, Published online 9 September 2016

\begin{abstract}
Arrested development of abomasal trichostrongylid nematodes was studied in 30 permanent grazing lambs on a large farm in the North-East of Algeria. The steppe climate has cold winters and hot and dry summers. The lambs were monitored monthly for gastrointestinal nematodes using nematode faecal egg counts, from February 2008 to February 2009. Every 2 months, two of the original 30 permanent lambs were necropsied after being held in pens for three weeks so that recently ingested infective larvae could develop into adults. The highest percentage of fourth stage larvae (L4), reaching $48 \%$ of the total worm burden, was recorded in abomasal contents in June. Teladorsagia and other Ostertagiinae constituted the highest percentage of L4 larvae (71\%), whereas the percentage of Trichostrongylus (17.4\%) or Haemonchus (11.6\%) remained low. The dynamics of infection observed here (highest faecal egg count in August) and the stage composition of worm burden (highest percentage of L4 in June) provide strong evidence that arrested development had occurred.
\end{abstract}

Key words: Arrested development, Abomasum, Teladorsagia, Steppe Climate, Lambs, Algeria.

\begin{abstract}
Résumé - Arrêt du développement des Nématodes Trichostrongles de la caillette des agneaux dans un environnement steppique (Nord-Est Algérien). L'arrêt du développement chez les nématodes trichostrongylidés de la caillette a été étudié chez trente agneaux en pâturage permanents d'une grande ferme dans le Nord-Est de l'Algérie. Le climat de steppe a des hivers froids et des étés chauds et secs. Les agneaux ont été suivis mensuellement pour les nématodes gastro-intestinaux en utilisant le nombre d'œufs de nématodes fécaux, de février 2008 à février 2009. Tous des deux mois, deux des trente agneaux permanents originaux ont été autopsiés après avoir été détenus dans des enclos pendant trois semaines afin que les larves infectantes récemment ingérées puissent se développer en adultes. Le pourcentage le plus élevé de larves de quatrième stade (L4), atteignant $48 \%$ de la charge parasitaire totale, a été enregistré dans le contenu de la caillette en juin. Teladorsagia et d'autres Ostertagiinae constituaient le pourcentage le plus élevé des larves L4 (71\%), alors que les pourcentages de Trichostrongylus (17.4\%) ou d'Haemonchus (11.6\%) restaient faibles. La dynamique de l'infection observée ici (excrétion fécale des œufs la plus élevée en août) et la composition en stades de la charge parasitaire (plus haut pourcentage de L4 en juin) fournit des preuves solides qu'un arrêt du développement a eu lieu.
\end{abstract}

\section{Introduction}

The life cycle of many nematodes can be delayed by the development of free-living larval stages or an arrest of development in the host referred to as hypobiosis. This enables the parasite to have available a large number of infective forms at times in the host life cycle that coincide with the presence of susceptible young lambs, thus ensuring transmission from one generation to the next $[9,19,23]$. Lambs in the northern

\footnotetext{
*Corresponding author: jacques.cabaret@tours.inra.fr
}

hemisphere are put out to graze at the beginning of spring, a time when the arrested larvae in ewes have resumed their development and have become reproductive adults shedding eggs onto pastures grazed by lambs $[5,9,26]$. Arrested development of a short or intermediate duration increases the destabilising effect on populations, whereas arrest of a duration of 5 months or more can stabilise interactions, irrespective of the regulation of the host population dynamics [16]. Arrested development in trichostrongylid nematodes is mostly recorded in regions with long cold winters [5, 9, 23,33]. Cold winter hypobiosis is characterised by larvae in the mucosae and a long 
duration of more than 4 months. Dry-season hypobiosis was first described by Graber and Tager-Kagan in 1975 [20] in cattle grazed in arid zones of Niger. It was further recorded in sheep bred under tropical climates with a dry season (unfavourable for development of free-living stages) [10, 29, 38] or very dry climates such as Saudi Arabia [13]. It was later recorded in regions with dry summers and cold winters (Middle-Atlas of Morocco [7]; North-Western Syria [18]). In dry-season hypobiosis, the duration is short (1 or 2 months) and the larvae are mostly found in the abomasal content. Summer arrest of development has also been shown in various climates in the southern hemisphere, including South Africa [33] and Australia [30]. Only one type of hypobiosis has been recorded in winter in Europe [26, 34] or summer in Syria [18], or both in Morocco [7], and is related mostly to Teladorsagia circumcincta. The aim of this study was to evaluate the prevalence of arrested development throughout the year in a steppe environment. Due to the cold winters and dry and hot summers, we may expect that both winter- and summerarrested development are present in this type of climate.

\section{Materials and methods}

\section{Farm studied and local climate}

The farm studied was located in the Batna region of NorthEast Algeria. The farm managed 1200 Ouled Djallel sheep, grazed partly on communal pastures with other ruminants owned by neighbouring small-holder farmers from October to May, although they were partially maintained in a sheepfold in winter. They were grazed on cereal stubble and crop residues from the end of June to September. Their grass diet was partly supplemented from October to February, and the main lambing period was in the autumn. The 1200 sheep were distributed into four independent flocks of 300 lambs. We studied one flock which was not treated during the year of study. Climatic data are presented in Figure 1. According to Emberger [14], Batna is located in a semi-arid bioclimatic zone with cold winters and could be characterised as a steppe climate according to the criterion of Viers and Vigneau [40]: steppe yearly rainfall $(\mathrm{R}$ in $\mathrm{cm}$ ) is below $40 \mathrm{~cm} /$ year and related to yearly average temperatures $\left(\mathrm{t}\right.$ in $\left.{ }^{\circ} \mathrm{C}\right)$ in the following way: $\mathrm{R}<2 \mathrm{t}$. The coldest month in the area is January (average $5.3{ }^{\circ} \mathrm{C}$ ) and the hottest is July (average $25^{\circ} \mathrm{C}$ ) based on 30 -year records. The coldest months in 2009-2010 were November-February (below $5{ }^{\circ} \mathrm{C}$ for minimum temperatures), which are not favourable for the development of free-living stages [22, 28, 32]. The hottest months in 2009 were June-August (above $33{ }^{\circ} \mathrm{C}$ maximum temperatures) with rainfall below $14 \mathrm{~cm}$ and low relative humidity (30-40\%); these conditions are not favourable for the development of free-living stages [22, 28, 32].

\section{Parasitological analyses}

Thirty weaned lambs aged 3-4 months were selected among available lambs and were used as sentinels to monitor gastrointestinal nematode (GIN) infection between February 2008

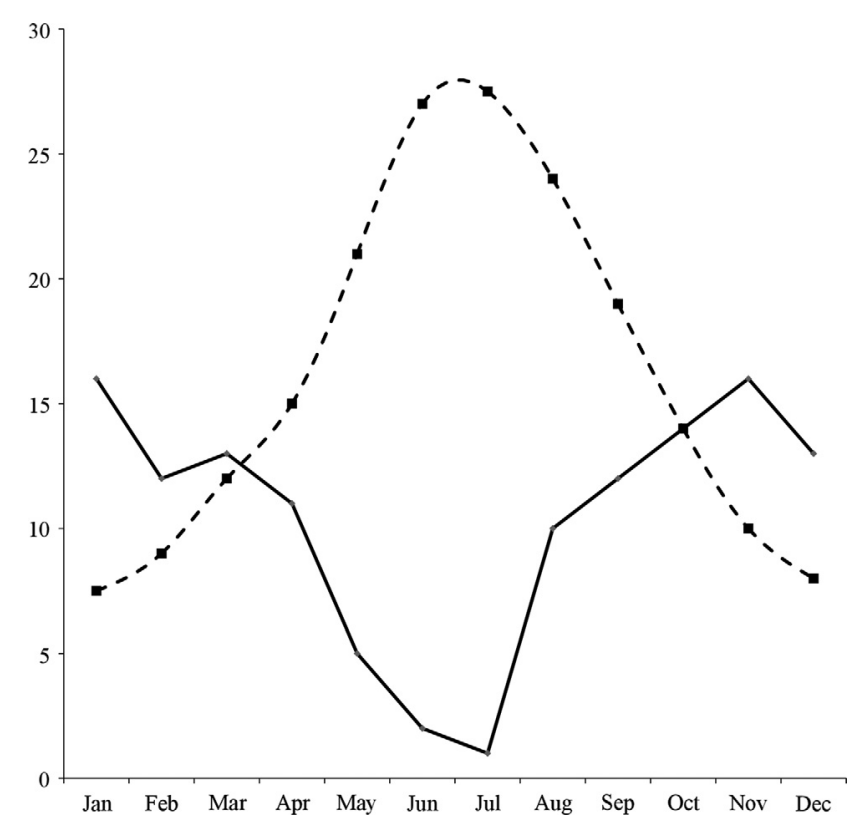

Figure 1. Monthly average temperature and rainfall in Batna: Data of 34 years (1974-2008) provided by the meteorological station in Batna (Algeria). Dashed line: temperature $\left({ }^{\circ} \mathrm{C}\right)$; solid line: rainfall $(\mathrm{cm})$.

and February 2009. They were not tracer lambs but rather permanent grazing lambs since they remained on pastures for the period; their number decreased progressively since two of them were necropsied each month. No anthelmintic treatments were given to the studied lambs during the study period. The rest of the flock also remained untreated. Faecal egg counts (number of eggs per gram of faeces: EPG) were carried out using a modified McMaster method [31] with an $\mathrm{NaCl}$ solution (1.18 specific gravity) sensitive to 15 EPG. When the McMaster method did not detect any eggs, a flotation method was also used, determined to be sensitive to 7.5 EPG. The eggs could be differentiated into Marshallagia marshalli and other gastrointestinal nematodes (GIN), the former being much larger (160-200 $\mu \mathrm{m}$ versus $60-110 \mu \mathrm{m}$, in Kassai, 1999 [21]). Every 2 months, two lambs were necropsied to identify the species of GIN and their larvae (L4 larvae and juvenile fifth stage). The lambs were held in pens for 3 weeks in order to allow the recently ingested larvae to develop into adults; the L4 larvae could then be considered as arrested since they should have developed into adults in that time. The necropsies were conducted according to MAFF (Ministry of Agriculture, Fisheries and Food) [24] and the adult GIN species were identified based on the criteria described by Skrjabin et al. [36] and morphs [8]. The larvae were identified according to Douvres (1957) [12] and Thomas and Probert (1993) [38]. The L4s were identified as Ostertagiinae since the L4 of M. marshalli is not described. The contents of the abomasum were sedimented in water several times until the supernatant was free of debris, and the adults and larvae of the GINs could then be identified and counted on a 1/5-1/10 aliquot. The abomasal mucosa was digested by incubation at $37^{\circ} \mathrm{C}$ for $20 \mathrm{hr}$ in pepsin hypochloric acid solution $(10 \mathrm{~g}$ pepsin, $30 \mathrm{~mL}$ hypochloric acid and $1000 \mathrm{~mL}$ 
distilled water as described in Giangaspero et al. [18]). The resulting suspension was then sieved through a $32 \mu \mathrm{m}$ mesh and the larvae were counted.

\section{Statistical analyses}

The dynamics of infection intensity (based on EPG or worm counts) were analysed using the non-parametric Kruskal-Wallis test. Additionally, a logarithmic transformation for an analysis of variance (ANOVA) was carried out, followed by a post hoc Newman-Keuls test to classify the months into high or low infection periods based on EPG in faeces, and adults or larvae recovered at necropsy. All statistical analyses were performed using SPSS 11.5 software. The percentages of $\mathrm{L} 4 \mathrm{~s}$ and juveniles were calculated by the following formulae:

Percentage of L $4 \mathrm{~s}$ of a species $=$ number of L $4 \mathrm{~s}$ of the species $\times 100 /$ total number of L4s.

Percentage of $\mathrm{L} 4 \mathrm{~s}$ in community $=$ number of $\mathrm{L} 4 \mathrm{~s}$

$$
\times 100 / \text { number }(\mathrm{L} 4 \mathrm{~s}+\text { juveniles }+ \text { adults }) .
$$

Percentage of juveniles of a species $=$ number of juveniles

of the species $\times 100 /$ total number of juveniles.

Percentage of juveniles in community $=$ number of juveniles

$$
\times 100 / \text { number }(\mathrm{L} 4 \mathrm{~s}+\text { juveniles }+ \text { adults }) .
$$

\section{Results}

\section{Presence of reproductive worms: dynamics of nematode egg faecal excretion}

The dynamics of faecal egg excretion of M. marshalli and other GINs are shown in Figure 2. According to the KruskalWallis test, excretion varied significantly between the months $(p=0.001)$. The univariate ANOVA indicated that excretion of other GINs was significantly higher in August compared to all other months $(p=0.001)$. Egg excretion of M. marshalli was significantly higher in autumn, particularly in November $(p=0.02)$.

\section{Presence of several GIN species: seasonal dynamics}

The different species of adult worms and their larvae observed in the six necropsies are reported in Table 1. The most abundant group of L4s observed was the Ostertagiinae in June, accounting for $71 \%$ of the L4 burden and $48 \%$ of the total worm burden (L4s/(L4s + juveniles + adults))

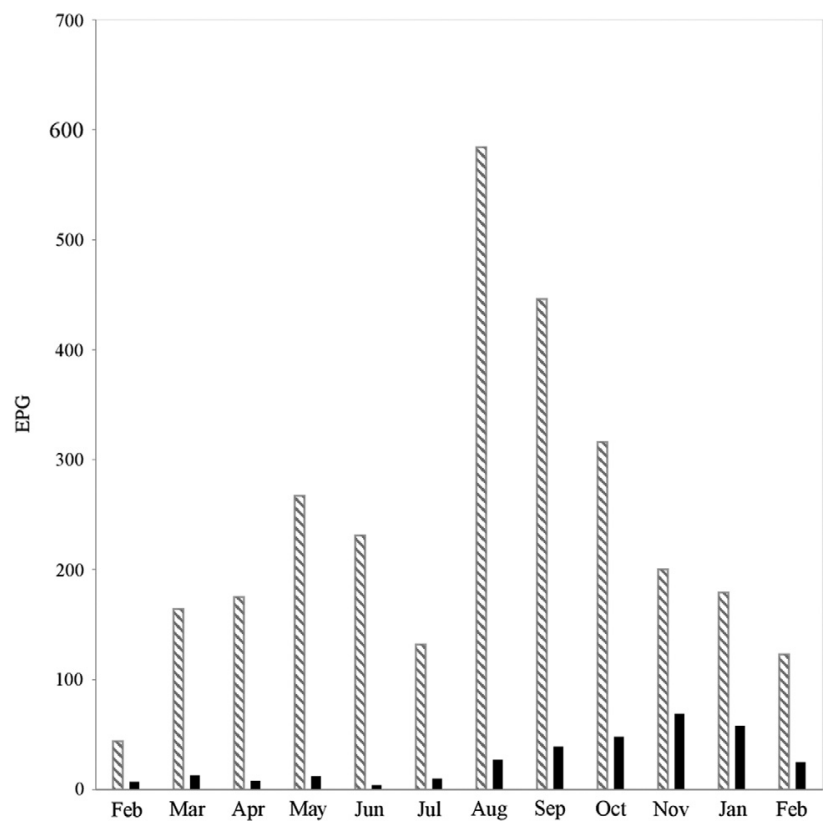

Figure 2. Seasonal dynamics of gastrointestinal nematode eggs per gram of faeces (EPG). Striped line: gastrointestinal nematodes; black line: Marshallagia marshalli.

(Table 1). The percentage of Haemonchus contortus L4s in June was $11.6 \%$. In August, the percentage of L4s in the community decreased, accounting for only $2.6 \%$ of the total worm burden, and the number of juveniles increased and reached a peak of 350 worms, representing $6.9 \%$ of the worm burden. There were two dominant adult abomasal nematode species throughout the summer period (in August): Teladorsagia circumcincta $(p=0.07)$ and $H$. contortus ( $p=0.06)$ (non-parametric Kruskal-Wallis test). M. marshalli was the predominant species detected in autumn-winter. The percentage of the minor morphs of $T$. circumcincta (T. c. trifurcata) was $7 \%$ with variations from $4 \%$ in high-level infections (August) to $14 \%$ in low-level infections.

\section{Arrested L4 larvae: seasonal dynamics}

Statistical analyses with ANOVA showed significant differences in the numbers of Ostertagiinae and $H$. contortus fourth stage larvae (L4s) between months ( $p=0.008$; $p=0.001$, respectively). The numbers of L4s of Ostertagiinae and $H$. contortus were found to be highest in June (ANOVA and post hoc Newman-Keuls test). Few L4s (L4/(L4s + juveniles + adults)) were found in lambs examined in winter $(2.3 \%$ in December and $0 \%$ in February 2009). The L4s in mucosae were found in April (20.5\%). They were found in the lumen at a high percentage in June (48.3\%). A significant peak of juvenile Ostertagiinae was recorded in August (ANOVA, $p=0.01$ ). The percentage of juveniles increased from $1.1 \%$ in June to $6.9 \%$ in August and this was an indication that L4 had resumed their development. 
Table 1. Composition of the abomasal worm community (larvae L4, juveniles and adult worms) of lambs during the six occasions of necropsy.

\begin{tabular}{|c|c|c|c|c|c|c|}
\hline Month & April & June & August & October & December & February \\
\hline \multicolumn{7}{|l|}{ Mean number of adult worms } \\
\hline Teladorsagia circumcincta morph circumcincta & 107 & 670 & 2366 & 215 & 37 & 12 \\
\hline Teladorsagia circumcincta morph trifurcata & 30 & 0 & 91 & 60 & 22 & 16 \\
\hline Haemonchus contortus & 0 & 0 & 917 & 271 & 78 & 60 \\
\hline Marshallagia marshalli** & 87 & 230 & 1099 & 1561 & 689 & 188 \\
\hline Trichostrongylus vitrinus & 0 & 0 & 140 & 69 & 0 & 8 \\
\hline Trichostrongylus axei & 0 & 0 & 0 & 69 & 6 & 0 \\
\hline Total & 224 & 900 & 4613 & 2245 & 832 & 284 \\
\hline Mean number of L4s & 58 & 860 & 135 & 0 & 20 & 0 \\
\hline \multicolumn{7}{|l|}{ Percentage of L $4 \mathrm{~s}$ of } \\
\hline T. circumcincta and other Ostertagiinae & 53.4 & 71 & 14.8 & 0 & 50 & 0 \\
\hline Haemonchus contortus & 0 & 11.6 & 11.1 & 0 & 0 & 0 \\
\hline Trichostrongylus sp. & 46.6 & 17.4 & 74 & 0 & 50 & 0 \\
\hline Percentage of L4s in community (L4s/(L4s + juveniles + adults $))$ & $20.5^{*}$ & 48.3 & 2.6 & 0 & $2.3^{*}$ & 0 \\
\hline Mean number of juveniles & 0 & 20 & 350 & 0 & 10 & 0 \\
\hline \multicolumn{7}{|l|}{ Percentage of juveniles of } \\
\hline T. circumcincta and other Ostertagiinae & 0 & 100 & 100 & 0 & 0 & 0 \\
\hline Trichostrongylus sp. & 0 & 0 & 0 & 0 & 100 & 0 \\
\hline Percentage of juveniles in community (juveniles/(juveniles + L4s + adults)) & 0 & 1.1 & 6.9 & 0 & 1 & 0 \\
\hline
\end{tabular}

\section{Discussion}

The main abomasal worm species found in the area were T. circumcincta and M. marshalli. The same fauna has also been recorded on farms in eastern Algeria by Bentounsi et al. [4], in Iraq by Altaif and Issa [1], in Syria by Giangaspero et al. [18] and in Morocco by Cabaret [7], as well as in various sites studied in a meta-analysis of the steppe region by Meradi et al. [25] or other similar regions by Suarez and Cabaret [37]. Under the same steppe climate, the faecal egg excretion dynamics found in Algeria by Bentounsi et al. [4] or Boulkaboul and Moulaye [6] showed two peaks of excretion of eggs, one in spring and one in autumn. This differed slightly from the dynamics of EPG observed in this study, as a single highest peak occurred from August to September. It is possible that these discrepancies result from the study of lambs exposed to different anthelmintic treatment regimes, as they were untreated in the present study; this was not the case in the other studies. The other reason could be that the fauna in the different sites might be different (large presence or not of intestinal Trichostrongylus sp., which was not evaluated in our study). The anthelmintic treatments in these areas were usually carried out in July or August when the lambs exhibit a peak of nematode egg excretion, and then in winter; all sheep are treated. The status of infection by adult GINs in European and North African studies is not very different from what has been recorded in the southern hemisphere, whether in Australia [11] or South Africa [33], where cold winters are associated with hot and dry summers. However, the presence of $M$. marshalli was not recorded. The frequency of the minor morph of T. circumcincta is higher than in Morocco (7\% vs. $3 \%$ ) but much lower than in other reports from more favourable climates where values of $20 \%$ are recorded [8].
The dynamics of the L4s (mostly $T$. circumcincta) was also seasonal, reaching a peak in June to represent $48 \%$ of the total worm burden. At this time, the L4s were found in the abomasal contents and not in the mucosa, which is the usual situation of winter-arrested larvae [3, 5, 27]. Large numbers of summerarrested larvae have also been found in Syria [18], where they represented $85 \%$ of the total worm burden, and other regions with a long dry summer, i.e. Saudi Arabia [13], and Eastern Ethiopia [35]. In the Middle-Atlas of Morocco, both winter and summer peaks of L4s were recorded over three consecutive years [7]. The L4 summer peaks in the present study did not correspond exactly to the classification of hypobiosis in trichostrongylid nematodes given that the L4s here were not found in the mucosa [27]. However, according to Michel [26], occurrence of hypobiosis can be indicated by one of the two factors: a) the presence of the same immature stage when there has been no sudden uptake of infective larvae, and b) the continued presence of immature stages after withdrawal from infection when sheep are kept in a sheep pen longer than the pre-patent period. The results from this study clearly meet the second condition, since the lambs were kept in a pen for 3 weeks before slaughter and thus did not ingest infective larvae. It was more difficult to verify the first condition given that we had no knowledge of the availability of infective larvae on pasture. Nonetheless, the dynamics of infection observed here (highest faecal egg count in August) and the stage composition of the worm burden (highest percentage of L4 in June) provide strong evidence that arrested development occurred. This arrest appeared in June when the temperature was at its highest, the rainfall levels were negligible and the sheep were grazed on stubble fields with limited vegetation at the end of June. Both high temperatures and low moisture are extremely difficult conditions for the 
development of free-living stages [22, 28, 32]. It appears that larval arrest is largely triggered by climatic variables in winter [15] and probably in summer. In this study, $71 \%$ of arrested L4s were Ostertagiinae in June. It is likely that these were T. circumcincta. The Marshallagia adult population was low in summer and no hypobiosis was detected. Trichostrongylus sp. showed high percentages of L4s in April and August and this could also be considered as arrested development. Low levels of $H$. contortus L4s were also observed in June $(11.6 \%)$, but it is unlikely that this corresponds to hypobiosis, but rather to the normal turnover of infection. This could be explained by the fact that the study region has a steppe climate and $H$. contortus is better adapted to a tropical climate [22]. Interestingly, $H$. contortus is the most commonly recorded GIN species to undergo hypobiosis during summers in dry/ hot areas $[2,10,17,29,39]$. It is possible that the differing results in the present study may be attributed to the cold winters that interrupt the hot summers in the study area, which may explain the low percentage of $H$. contortus and the absence of summer hypobiosis for this species.

\section{Conflict of interest}

This work was in part funded by a National Research Programme (PNR) from the Ministry of Higher Education and Scientific Research (PNR, I/U250, 233). All authors voluntarily publish this article and have no personal interest in these studies other than publishing the scientific findings that they have been involved in developing, via planning, initiating, monitoring and conducting the investigations and analysing the results.

Acknowledgements. We thank the heads of the El Mader farm of Batna, mainly Boubidi Houcine and Tarfaya Nourredine, in addition to the animal health technician Kisri Slimane, for their support in carrying out this work. Caroline Chylinski commented on an earlier draft of the paper and revised the English language.

\section{References}

1. Altaif KI, Issa WH. 1982. Seasonal fluctuations and hypobiosis of gastrointestinal nematodes of Awassi lambs in Iraq. Parasitology, 86, 301-310.

2. Allonby EW, Urquhart GM. 1975. The epidemiology and pathologic significance of haemonchosis in a merino flock in east Africa. Veterinary Parasitology, 1, 129-143.

3. Armour J. 1970. Bovine ostertagiasis: a review. Veterinary Record, 86, 184-189.

4. Bentounsi B, Mecif A, Kohil K. 2001. Évolution du parasitisme ovin sur un élevage de la région du Khroub. Approche par les méthodes coproscopiques. Science et Technologie, 16, 51-54.

5. Blitz NM, Gibbs HC. 1972. Studies on the arrested development of Haemonchus contortus in sheep: I. The introduction of arrested development. International Journal of Parasitology, 2, $5-12$.

6. Boulkaboul A, Moulaye K. 2006. Parasitisme interne du mouton de race Ouled Djellal en zone semi-aride d'Algérie. Revue d'Élevage et de Médecine Vétérinaire des Pays Tropicaux, 59(14), 23-29.
7. Cabaret J. 1984. Seasonal changes in the abomasal nematodes of naturally infected ewes in Moulay Bouazza (Morocco). Veterinary Parasitology, 15, 47-56.

8. Cabaret J, Morales G, Gruner L. 1984. Characteristics of Teladorsagia circumcincta and Teladorsagia trifurcata. 1. Epidemiological and biological aspects. Annales de Parasitologie Humaine et Comparée, 59, 607-617.

9. Capitini LA, McClure KE, Herd RP. 1990. Effect of environmental stimuli on pre-infective and infective stages of Haemonchus contortus in the Northern United States for the induction of hypobiosis. Veterinary Parasitology, 35, 281-293.

10. Chiejina SN, Fakae BB, Eze BO. 1988. Arrested development of gastrointestinal trichostrongylids in goats in Nigeria. Vet Parasitology, 28, 103-113.

11. Donald AD, Morley FHW, Waller PJ, Axelsen A, Donnelly JR. 1978. Availability to grazing sheep of gastrointestinal nematode infection arising from summer contamination of pastures. Australian Journal of Agricultural Research, 29(1), 189-204.

12. Douvres FW. 1957. Keys to the identification of the immature parasitic stages of gastrointestinal nematodes of cattle. American Journal Veterinary Research, 18, 81-85.

13. El-Azazy OME. 1995. Seasonal changes and inhibited development of the abomasal nematodes of sheep and goats in Saudi Arabia. Veterinary Parasitology, 58, 91-98.

14. Emberger L. 1930. Sur une formule applicable en géographie botanique. Comptes Rendus de l'Académie des Sciences, 191, 389-390.

15. Fernández AS, Fiel CA, Steffan PE. 1999. Study on the inductive factors of hypobiosis of Ostertagia ostertagi in cattle. Veterinary Parasitology, 81, 295-307.

16. Gaba S, Gourbiere S. 2008. To delay once or twice: the effect of hypobiosis and free-living stages on the stability of hostparasite interactions. Journal of Royal Society Interface, 5, 919-928.

17. Gatongi PM, Prichard RK, Ranjan S, Gathuma JM, Munyua WK, Cheruiyot H, Scott ME. 1998. Hypobiosis of Haemonchus contortus in natural infections of sheep and goats in a semi-arid area of Kenya. Veterinary Parasitology, 77, 49-61.

18. Giangaspero M, Thomson EF, Orita G, Bahhady FA, Rhodes C. 1992. Effect of gastrointestinal parasite and lungworm control on survivability and fertility of ewes in farm flocks in Syria. Tropical Animal Health and Production, 78, 594-597.

19. Gibbs HC. 1982. Mechanisms of survival of nematode parasites with emphasis on hypobiosis. Veterinary Parasitology, 11, 25-48.

20. Graber M, Tager-Kagan P. 1975. Inhibition du développement des larves de Cooperia punctata et de Cooperia pectinata chez le Zébu nigérien. Revue d'Élevage et de Médecine Vétérinaire des Pays Tropicaux, 28, 137-142.

21. Kassai T. 1999. Veterinary helminthology. ButterworthHeinemann: Oxford. p. 260.

22. Kates KC. 1965. Ecological aspects of helminth transmission in domesticated animals. American Zoologist Journal, 5, 95-130.

23. Langrová I, Makovcová K, Vadlejch J, Jankovská I, Petrtýl M, Keil P, Lytvynets A, Borkovcová M. 2008. Arrested development of sheep strongyles: onset and resumption under field conditions of Central Europe. Parasitology Research, 103, 387-392.

24. MAFF (Ministry of Agriculture, Fisheries and Food). 1986. Manual of Veterinary Parasitology Laboratory Techniques. London: HSMO Books. 
25. Meradi S, Bentounsi B, Zouyed I, Cabaret J. 2011. The steppe species of gastrointestinal nematodes of small ruminants, with a focus on Marshallagia: climate as a key determinant. Parasite, 18, 261-269.

26. Michel JF. 1974. Arrested development of nematodes and some related phenomena. Advances in Parasitology, 12, 279-366.

27. Michel JF, Lancaster MB, Hong C. 1974. Studies on arrested development of Ostertagia ostertagi and Cooperia oncophora. Journal of Comparative Pathology, 84, 539-554.

28. O'Connor LJ, Walkden-Brow SW, Kahn LP. 2006. Ecology of the free-living stages of major trichostrongylid parasites of sheep. Veterinary Parasitology, 142, 1-15.

29. Ogunsusi RA, Eysker M. 1979. Inhibited development of trichostrongylids of sheep in Northern Nigeria. Research in Veterinary Science, 26, 108-110.

30. Pullman AL, Beveridge I, Martin RR. 1988. Epidemiology of nematode infections of weaner sheep in the cereal zone of South Australia. Australian Journal of Agricultural Research, 39(4), 691-702.

31. Raynaud JP. 1970. Étude de l'efficacité d'une technique de coproscopie quantitative pour le diagnostic de routine et le contrôle des infestations parasitaires des bovins, ovins, équins et porcins. Annales de Parasitologie Humaine et Comparée, 45, 321-334.

32. Rossanigo CE, Gruner L. 1995. Moisture and temperature requirements in faeces for the development of free-living stages of gastrointestinal nematodes of sheep, cattle and deer. Journal of Helminthology, 69, 357-362.
33. Rossiter LW. 1964. The epizootiology of nematode parasites of sheep in the coastal area of the Eastern Province. Onderstepoort Journal of Veterinary Research, 31, 143-150.

34. Sargison ND, Wilson DJ, Bartley DJ, Penny CD, Jackson F. 2007. Haemonchosis and teladorsagiosis in a Scottish sheep flock putatively associated with the overwintering of hypobiotic fourth stage larvae. Veterinary Parasitology, 147, 326-331.

35. Sissay MM, Uggla A, Waller PJ. 2007. Epidemiology and seasonal dynamics of gastrointestinal nematode infections of sheep in a semi-arid region of eastern Ethiopia. Veterinary Parasitology, 143, 311-321.

36. Skrjabin KI, Shikobalova NP, Shultz RS. 1954. Trichostrongylids of Animal and Man. National Science Foundation. Department of Agriculture: Washington. p. 483.

37. Suarez VH, Cabaret J. 1991. Similarities between species of the Ostertaginae (Nematoda: Trichostrongylidae) in relation to host-specificity and climatic environment. Systematic Parasitology, 20, 179-185.

38. Thomas DR, Probert AJ. 1993. A key to the identification of arrested gastrointestinal nematode larvae of sheep in Britain. Veterinary Parasitology, 47(1-2), 77-80.

39. Vercruysse J. 1985. The seasonal prevalence of inhibited development of Haemonchus contortus in sheep in Senegal. Veterinary Parasitology, 17, 159-163.

40. Viers G, Vigneau JP. 1990. Éléments de climatologie. Paris: Nathan.

Cite this article as: Meradi S, Cabaret J \& Bentounsi B: Arrested development of abomasal trichostrongylid nematodes in lambs in a steppe environment (North-Eastern Algeria). Parasite, 2016, 23, 39.

\section{OP PARASTE}

An international open-access, peer-reviewed, online journal publishing high quality papers on all aspects of human and animal parasitology

Reviews, articles and short notes may be submitted. Fields include, but are not limited to: general, medical and veterinary parasitology; morphology, including ultrastructure; parasite systematics, including entomology, acarology, helminthology and protistology, and molecular analyses; molecular biology and biochemistry; immunology of parasitic diseases; host-parasite relationships; ecology and life history of parasites; epidemiology; therapeutics; new diagnostic tools.

All papers in Parasite are published in English. Manuscripts should have a broad interest and must not have been published or submitted elsewhere. No limit is imposed on the length of manuscripts.

Parasite (open-access) continues Parasite (print and online editions, 1994-2012) and Annales de Parasitologie Humaine et Comparée (1923-1993) and is the official journal of the Société Française de Parasitologie. 